\title{
Deferential Federalism: The Politics and Policy Implications of ‘Collaborative' Federalism Since 1994
}

\section{Gregory Wilford \\ University of Western Ontario}

The topic of this essay is Canada's evolving federalism. It will examine the development of "collaborative federalism" ${ }^{1}$ in Canada since the mid-1990s, analysing the politics operating behind it in order to i) detail the stances taken by recent federal governments in their dealings with the provinces and ii) show the consequences of these stances on national policy objectives and social programs. It is this author's contention that federal governments over the last two decades have intermittently engaged in convenient deference toward their provincial counterparts and that, when this has been done, it has been detrimental to pan-Canadian policy objectives generally and social programs in particular. First of all, the Agreement on Internal Trade (AIT) of 1994 showcases the weaknesses of framework-oriented policy initiatives that characterize collaborative arrangements. Next, the Canada Health and Social Transfer (CHST) created in the 1995 federal budget highlights how easily the federal government can defer greater authority onto the provinces and what this means for social programs. What is more, the Social Union Framework Agreement (SUFA) of 1999 and the attendant agreement on

\footnotetext{
${ }^{1}$ Yulia Minaeva, "Canadian Federalism Uncovered: The Assumed, the Forgotten and the Unexamined in Collaborative Federalism," (Ph.D. thesis, University of Ottawa, 2012), 13. 'Collaborative federalism' used from here on in the essay as defined by Yulia Minaeva. Collaboration in the context of federal-provincial interaction entails a certain degree of qualification in key areas; namely, that there is “ i) shared authority and power, ii) shared resources, iii) implementation of joint activities and provision of services to achieve collaborative results, and iv) information sharing." It should be noted here that the agreements and accords discussed in this paper, which have been called 'collaborative' by governments and in news articles, do not on Minaeva's examination fully satisfy her concept of true 'collaboration', though they may be considered attempts at collaboration.
}

health care funding show the potential for the exercise of federal spending power even within collaborative arrangements. Finally, the early interaction of the current Conservative government with the provinces under a stance known as 'open federalism' provides a few cases in point of how policy objectives may be pursued in the present and near future, and points to consequences for social programs in Canada.

Looking into the immediate background of federal-provincial relations prior to 1994 helps to put the marked changes of the mid-1990s into context. To begin, the country had just come out of two failed attempts at constitutional reform with the Meech Lake Accord of 1987 and the Charlottetown Accord of 1992, and the "upshot of these two events was the realization that fundamental constitutional change was not a feasible option." ${ }^{2}$ That is to say, politicians in both levels of government were now likely to stay away from further constitutional bargaining; permanent and significant legal alteration was not popular with the public or the provincial governments concerned, nor was it easy. But there was also financial and ideological pressure to change. The federal government spent actively throughout the 1970's and weathered two major recessions so that "Canada experienced successive federal budget deficits." ${ }^{3}$ To be sure, there was an effort to limit government spending during this time as Trudeau's Liberal government cut $\$ 963$ million $^{4}$ in

\footnotetext{
${ }^{2}$ Minaeva, "Canadian Federalism Uncovered: The Assumed, the Forgotten and the Unexamined in Collaborative Federalism," 8.

${ }^{3}$ Simon Lee, "The Governance of Fiscal Policy in the United Kingdom and Canada," Journal of Comparative Policy Analysis 5, no. 2-3 (Jun 2003, 2003): 177.

${ }^{4}$ Lee, "The Governance of Fiscal Policy in the United Kingdom and Canada," 177.
} 
1975 and $\$ 2.5$ billion $^{5}$ in 1978 and the Conservatives under Mulroney saw an $\$ 8.7^{6}$ billion drop in the deficit between1984-88. Still "these attempts at retrenchment were not entirely successful." 7 Moreover, major external developments, the "policies of Ronald Reagan and Margaret Thatcher...and globalization," were also "putting pressure on Canada to make reforms." 8 Internally, business lobbies such as the Business Council on National Issues and neoliberal think tanks such as the Fraser Institute and C.D. Howe Institute started to push for market friendly reform, especially during the "Canada Round" of negotiations leading up to the Charlottetown Accord. ${ }^{9}$ It followed that the "ideological persuasions, and the increasing salience of government deficits" were not yet satisfactorily addressed. ${ }^{10}$

This led into the negotiation of the AIT in 1994, the first major instance of a frameworkoriented policy initiative and one that typifies the potential weakness of collaborative federalism. The AIT was a way for the two levels of government to "revive the economic union provisions of the Charlottetown Accord through non-constitutional means" ${ }^{11}$ and therefore a fresh attempt to find new channels through which to reach consensus and work on the center-periphery relationship. The federal government had to avoid the hugely unpopular act of altering the Constitution or even invoking it in any renewed negotiations. In fact, in order to avoid aggravating

\footnotetext{
${ }^{5}$ Ibid., 177.

${ }^{6}$ Ibid., 177.

${ }^{7}$ Ibid., 177.

${ }^{8}$ Chris Edwards, "Canada's Fiscal Reforms," Cato Journal 33, no. 2 (Apr 2013, 2013): 300.

${ }^{9}$ Adam Harmes, "The Political Economy of Open Federalism," Canadian Journal of Political Science 40, no. 2 (Jun 2007, 2007): 429-430.

${ }^{10}$ Steven Edgar, "The Implications of Open Federalism for Canadian Social Citizenship," (M.A. thesis, Dalhousie University (Canada), 2008), 56.

${ }^{11}$ Harmes, "The Political Economy of Open Federalism," 431. He feels that this was also in response to pressure from the business lobby which put out studies and position literature calling for the breaking down of barriers to capital and labor mobility between provinces.
}

constitutional grievances, the Prime Minister and his Minister of Industry would not press the federal government's constitutional power over trade and commerce in negotiating the agreement on interprovincial trade. ${ }^{12}$ So the AIT depended on the success of negotiations and the commitment of the provinces without a coercive option for Chrétien's Liberal government to fall back on. This proved a difficult endeavour. From the outset, the talks were burdened by the fact that some of the provinces were better equipped than others for deliberation on the "technical aspects of the barriers to trade." ${ }^{13}$ The governments of "Ontario, Alberta and Quebec had the largest expert bureaucracies and the greatest trade policy capacity," for example, so that the "various sectoral tables" were dominated by advisors from these provinces. ${ }^{14}$ This meant that most technicalities were settled by these larger governments with the interests of smaller provinces figuring less prominently. This served to reduce the smaller province's drive to complete the negotiations as they saw the larger provinces settling many of the technical aspects of the talks while their delegates were unable to contribute. To further complicate matters, not all delegates were from the same "policy communities;" they branched into three distinct areas of expertise: "trade policy, regional development and industry, and [...] intergovernmental relations." ${ }^{15}$ Such variation of ideas as to the ultimate goal of the

\footnotetext{
${ }^{12}$ Minaeva, "Canadian Federalism Uncovered: The Assumed, the Forgotten and the Unexamined in Collaborative Federalism," 80. John Manley was the Minister of Labour at this time, 'grievances' here referring to both the publics' and the premiers' weariness of constitutional dispute.

${ }^{13}$ Edgar, "The Implications of Open Federalism for Canadian Social Citizenship," 84. The larger governments would know, for instance, more accurately how much each 'barrier' (i.e -restriction on capital and labour movement, or tax on certain goods) affected the overall balance of trade for their provinces. Which barriers were beneficial for themselves, or which barriers helped other provinces to their disadvantage.

${ }^{14}$ Minaeva, "Canadian Federalism Uncovered: The Assumed, the Forgotten and the Unexamined in Collaborative Federalism," 84.

15 Ibid., 84.
} 
agreement-with trade policy pundits tending to emphasize reducing barriers to trade while those in regional development pulled for protection of certain industries in their jurisdiction-made it even more difficult to "build a comprehensive approach to trade negotiations." ${ }^{16}$ In short the disparate backgrounds of provincial delegates led to miscommunication and fundamental disagreement as to the objectives of the trade agreement. Without the constitutional imperative to keep them focused on coming up with an agreement, the negotiations would inevitably be protracted. These negotiations are an example of 'collaborative federalism' and display the detrimental effects of the federal government deferring responsibility for policy to the provinces: nothing gets done.

Further, in these voluntary negotiations "involvement of elite actors ...was very selective," these actors being incentivized to "see policies primarily in terms of their jurisdictional impact." ${ }^{17}$ So the elite participated in the agreements only intermittently and when they did so they only had concern over what would impact their jurisdiction, they did not concern themselves with what would benefit Canada as a whole. Throughout this process the federal government was not using either its constitutional authority or penalization through the federal spending power and the agreement was legally non-binding. Its eventual signing was perhaps only due to "concerns over national unity," ${ }^{18}$ which is to say that the premiers may have signed the agreement based on a perception that Canadians might appreciate the symbolism. By the time the agreement was concluded it was highly ineffective due to a prior "watering down of many of its more neoliberal provisions." ${ }^{19}$ The provincial delegates had sought first and foremost to protect localized industries rather than expose them to more

\footnotetext{
16 Ibid., 86.

${ }^{17}$ Minaeva, "Canadian Federalism Uncovered: The Assumed, the Forgotten and the Unexamined in Collaborative Federalism," 86.

${ }^{18}$ Harmes, "The Political Economy of Open Federalism," 432.

${ }^{19}$ Ibid., 432.
}

liberalized trade. What obligations were set out in the agreement had little impact until, at the behest of the premiers in the Council of Federation, $2003 .{ }^{20}$ Even after the signing of the SUFA in 1999 when the First Ministers reaffirmed the most important commitment of the AIT to "resolve all outstanding barriers to [labour] mobility by July 1, 2001," this deadline was never met, there being "no mechanism to ensure the regulating bodies respected the obligations established by the AIT." ${ }^{21}$ Again without a constitutional imperative to see that the negotiations materialized, there was no incentive for the premiers and provincial governments to implement the specifics of the agreement or to see that its goals were met, so the frameworkoriented AIT itself had little impact on interprovincial trade policy. This seems to be the result of the federal government foregoing its constitutional authority and fiscal power in the spirit of 'collaborative' ${ }^{22}$ federalism, which perhaps would have incentivized the provincial governments to conclude a more comprehensive agreement which they then would have abided by. Again, leaving the negotiations in the hands of the provinces and deferring responsibility led to an indecisive trade policy which had no impact on policy due to its lack of federally-backed incentive.

Shortly after the AIT the federal government created the CHST, addressing national deficits through unilateral cuts to shared-cost programs to the provinces. In doing so it displayed how easily the federal government could move financial burden and thus implicit authority to

\footnotetext{
${ }^{20}$ Minaeva, "Canadian Federalism Uncovered: The Assumed, the Forgotten and the Unexamined in Collaborative Federalism," 91. And here there was a proliferation of bilateral agreements between provinces as these were better poised to produce "tailored solutions to specific problems" so that it seems "the dynamic of collaboration has been replaced by the dynamic of bilateralism in the Internal Trade Agreement." As Minaeva points out on page 103. ${ }^{21}$ Ibid., 91-92.

${ }^{22}$ The AIT itself failing on the third condition of collaboration, "iii) implementation of joint activities and provision of services to achieve collaborative results" (see first citation).
} 
provincial governments. And some consequences for social assistance programs also became apparent. The creation of the CHST transfers for social assistance under the 1966 Canada Assistance Plan were combined with transfers for post-secondary education and health care under the 1977 Established Program Financing Act "while reducing the cash portion of federal funding by about one third." ${ }^{23}$ This move has two important implications. First, the "vertical fiscal imbalance" it gave rise to, whereby the federal government accrues "large surpluses" while the provinces are "put in or near deficit (depending on the year)," quantifies the extent of federal disengagement. ${ }^{24}$ That is the extent to which the federal government can shift its responsibilities onto the provinces. Canada's federal debt as percentage of GDP had "declined from a peak of $71 \%$ in $1995-1996$ to below $53 \%$ at the end of 200 $2001^{\prime 25}$ while during the same period provinces "boosted spending on health and welfare by more than 30\%, almost double the increase in their aggregate budgets." ${ }^{26}$ This has been properly referred to as "the exercise of federal spending power in reverse." ${ }^{27}$ And though it was in the direction of devolving responsibility to the provinces, it still indicates the capacity of the federal government to implement fiscal change from the top-down. Here the federal government blatantly used its spending power in reverse for political reasons, the large surpluses that it could lay claim to made it look efficient and frugal while under the table provinces were having to meet greater obligations. This showcases the federal government's power or ability in exercising its spending power, regardless of the direction-

\footnotetext{
${ }^{23}$ Edgar, "The Implications of Open Federalism for Canadian Social Citizenship," 31-32.

${ }^{24}$ Ibid., 26-27.

${ }^{25}$ Lee, "The Governance of Fiscal Policy in the United Kingdom and Canada," 175.

${ }^{26}$ John Harles and Jamie Davies, "Federalism Matters: Welfare Reform and the Intergovernmental Balance of Power in Canada and the United States," Canadian American Public Policy, no. 61 (Jan 2005, 2005): 29.

${ }^{27}$ Minaeva, "Canadian Federalism Uncovered: The Assumed, the Forgotten and the Unexamined in Collaborative Federalism," 8.
}

either spending more on social program to boost pan-Canadian objectives or spending less to improve its fiscal position vis-à-vis the provinces. The result is simply that the federal government maintains a great capacity to influence spending across Canada. Second, partly due to this new fiscal imbalance but also enabled by the dismantling of the CAP requirement that needs tests be the "sole criterion of welfare eligibility," each of the provinces created stricter eligibility qualifications to cut program costs. ${ }^{28}$ Such qualifications passed since the creation of the CHST include Ontario's 1998 imposition of "mandatory employment...including unpaid community service work" and British Columbia's 2002 cut-off of benefits to "recipients without children, save the disabled" after two years. ${ }^{29}$ So the CHST provided both the incentive for and possibility of greater provincial limitations on welfare receipt. The provinces had to find ways to save money since there had been cutbacks in funding from the federal government and moreover the federal government made it easier for the provincial governments by suspending CAP requirements that welfare be provided on a needs basis. Hence, the shift in fiscal policy embodied in the CHST has shown the capacity of the federal government to defer programs, especially their costs, to the provinces while also highlighting some resulting retrenchment of social assistance programs. Although there was no collaboration this is an excellent example of unilateral deference as health and welfare policy was moved into the hands of provincial governments.

\footnotetext{
${ }^{28}$ Harles and Davies, "Federalism Matters: Welfare Reform and the Intergovernmental Balance of Power in Canada and the United States," 17.

${ }^{29}$ Harles and Davies, "Federalism Matters: Welfare Reform and the Intergovernmental Balance of Power in Canada and the United States," 19. Apart from significant changes since the CHST, provinces have a wide variance in "basic cash assistance," four provinces include the monthly supplement provided by the National Child Benefit in a "claw back" for calculating social assistance eligibility and Alberta requires that parents of children as young as six months "find paid work in return for assistance" see 17-19.
} 
The next development in federalprovincial relations was the signing of the 1999 SUFA, another framework-oriented collaboration this time meant to prevent "conflicts over neoliberal approaches to social policy renewal." ${ }^{30}$ But unlike the AIT, by the end of this agreement the federal spending power was reasserted and gave the federal government some legitimacy over programs under provincial jurisdiction. The process was started in March of 1998 by a joint "Federal/ Provincial/ Territorial Council on Social Policy Renewal" ${ }^{31}$ but the provinces were the party with something to gain. After the cuts of 1995 the provinces began "temporarily lining up with the Quebec position," the position that the federal spending power was illegitimate and in need of limitation. ${ }^{32}$ And early on, the Prime Minister told the provinces that i) the federal government would not use its spending power to establish any "Canada-wide shared-cost program" and ii) the provinces could opt-out of any such programs established in the future. ${ }^{33}$ Chrétien also wanted the SUFA to "ensure that governments work collaboratively and are publicly accountable." ${ }^{34}$ So the provincial governments entered the negotiations assured of a change in the way federal spending power would be used. They thought that more collaboration on future programs and an opt-out capability would provide greater autonomy in future program development. So they entered the talks with the understanding that the federal government would curtail its unilateral powers, and, with the prospect of greater autonomy in program development, the provinces had an incentive to come to the table;

\footnotetext{
${ }^{30}$ Barbara Cameron, "The Social Union, Executive Power and Social Rights," Canadian Woman Studies 23, no. 3/4 (Spring/Summer 2004, 2004): 53

${ }^{31}$ Minaeva, "Canadian Federalism Uncovered: The Assumed, the Forgotten and the Unexamined in Collaborative Federalism," 113.

${ }^{32}$ Cameron, "The Social Union, Executive Power and Social Rights," 50.

${ }^{33}$ Minaeva, "Canadian Federalism Uncovered: The Assumed, the Forgotten and the Unexamined in Collaborative Federalism," 115-116. Provided that they established a similar provincial program. ${ }^{34}$ Ibid., 117.
}

however, this changed in December of 1998 with a "federal proposal for a Health Accord" ${ }^{35}$ that would increase the CHST. This put pressure on the provinces as it was "contingent on" conclusion "in advance of the 1999 federal budget." ${ }^{36}$ The provinces decided to conclude the SUFA on February $4^{\text {th }} 1999$ and while coming to "an informal understanding that the federal government would increase health-related transfers" they gave up on their previous "demand for the ability to opt-out" ${ }^{\prime 37}$ of future pan-Canadian shared cost programs. As part of the attendant Health Accord the federal budget of 1999 promised $\$ 11.5$ billion ${ }^{38}$ over five years, the provinces reaffirmed their commitment to the principles of the Canada Health Act and "agreed to make available information on their respective health care systems." 39 Here the federal government shrewdly employed its spending power combined with time constraints to strongarm the provinces into accepting its pan-Canadian objectives. It reinforced the ability of the federal government to use its spending power even after promises to avoid such an exercise by unilaterally increasing funding for health care. It also conferred greater legitimacy on the federal government as greater funds were made available for health care. Thus, by this increase in funding the federal government had not only bought some provincial cooperation ${ }^{40}$ but had gained more political legitimacy via financial support over the provinces' health programs. This is an instance in which the federal government took responsibility for pan-Canadian health policy and the results are evident in that the provinces each followed its direction.

\footnotetext{
35 Ibid., 118.

${ }^{36}$ Ibid., 118.

${ }^{37}$ Ibid., 119.

${ }^{38}$ Kumanan Wilson, "Health Care, Federalism and the New Social Union," Canadian Medical Association Journal 162, no. 8 (Apr 18, 2000, 2000): 1173.

39 Ibid., 1173.

${ }^{40}$ The guarantee of commitment to the principles of $\mathrm{CHA}$ and of information sharing in exchange for increased funding was a clear exercise of the federal spending power.
} 
More recently, the Conservative government of Prime Minister Stephen Harper has provided a few examples of its own version of 'collaborative federalism' under a stance referred to as 'open federalism' which points to a very limited role for the federal government in programs under provincial jurisdiction. To start, the Universal Child Care Benefit created in the $2006{ }^{41}$ budget was a unilateral move which suggested an aversion for joint federal-provincial programs. Such a move hints at the capacity of the federal government to implement national programs without cooperation of the provinces. The UCCB replaced "bilateral agreements in principle (AIP)" signed between the Liberal government of Paul Martin and each of the provinces under the "Multilateral Framework Agreement on Early Learning and Child Care" or ELCC which dedicated a total of $\$ 5$ billion ${ }^{42}$ to be divided and paid out to the provinces for their respective five-year action plans. ${ }^{43}$ The UCCB was "not a program per se, but rather a tax benefit" worth less than the face value of $\$ 1200$ per child under six years of age since this was taxable income. ${ }^{44}$ Combined with their efforts to stimulate "the creation of up to 25,000 new child care spaces" ${ }^{45}$ this was still “\$400 million less a year" ${ }^{46}$ than the planned expenditure under the ELCC. The repudiation of the bilateral agreements of the previous government showcases the intent of Stephen Harper's so-called 'open federalism' as nothing more than another unilateral move to achieve the federal governments objectives of moving away from policy that involves the provinces, that means a scaling back of previous commitments in favour of a less-involved and cheaper scheme. It also displays the capacity once again of the federal government to impose its policy direction on the provinces without their consent. The way in which the Conservatives

\footnotetext{
${ }^{41}$ Edgar, "The Implications of Open Federalism for Canadian Social Citizenship," 34.

42 Ibid., 33.

${ }^{43}$ lbid., 33-34.

44 Ibid., 35.

${ }^{45}$ Ibid., 37.

${ }^{46}$ Ibid., 36.
}

dismantled the previous program, giving oneyear's notice to the provinces without consultation, ${ }^{47}$ indicates a one-sided approach to deciding changes in social policy. And using the tax system as opposed to funding provincial programs displays an inclination to avoid collaboration in implementation as well. 'Open federalism' then seems to entail a hands-off approach with minimal interaction with the provincial governments. With that being said, the UCCB was a prime example of the federal government taking the initiative and enforcing a pan-Canadian program with no deference to the provinces and no collaboration. Although this was a more modest program than the previous Liberal government had designed, it was still a step in the direction of more federal control; less collaboration in this instance meant a full program was effectively put into place.

The Conservatives did, however, launch a small initiative that may be considered an attempt at collaboration: ${ }^{48}$ the Patient Wait Times Guarantee Trust created in the $2007^{49}$ budget, which has been unambitious in scope and unsuccessful in its existing goals. The Trust was essentially a "pilot project fund" that put out $\$ 612$ million for the provinces to work on "implementation of wait time guarantees in at least one of the five priority areas." ${ }^{50}$ Initially promising improvement in the wait times of all five priority areas in the 2006 budget pledge, guaranteeing a single area was in fact a large reduction in scope. ${ }^{51}$ And there was no provision for furthering the establishment of "nationally

\footnotetext{
${ }^{47}$ Minaeva, "Canadian Federalism Uncovered: The Assumed, the Forgotten and the Unexamined in Collaborative Federalism," 136-137.

${ }^{48}$ Edgar, "The Implications of Open Federalism for Canadian Social Citizenship," 42. Since eligibility for a province depended on its conclusion of a written agreement with the federal government.

${ }^{49}$ Edgar, "The Implications of Open Federalism for Canadian Social Citizenship," 42.

${ }^{50}$ Minaeva, "Canadian Federalism Uncovered: The Assumed, the Forgotten and the Unexamined in Collaborative Federalism," 132. The priority areas being cancer, cardiac interventions, joint replacement, sight restoration and diagnostic imaging procedures.

${ }^{51}$ Edgar, "The Implications of Open Federalism for Canadian Social Citizenship," 42.
} 
comparable indicators and measurements systems" which has been on the national agenda since the 2003 Health Accord. ${ }^{52}$ In fact, even by 2008 the Canadian Institute for Health Information found that it was "impossible to compare and measure the progress on wait time reductions across the country," so that even if improvements did result from the Trust, the Conservatives would have very little evidence. ${ }^{53}$ Stemming partly from the fact that some of the "guarantees constitute either little improvement on current practices or promise wait improvements that fall short of the advice of medical professionals," and partly from the lack of "method for enforcement," the prospects for meaningful reduction in wait times seemed poor. ${ }^{54}$ The fact that this attempt was never equipped with the tools to quantify its success shows a lack of effort on the part of the federal government. The Conservatives could have attached requirements to the Trust fund that stipulated measures of performance in decreasing waiting times so that they could quantify any improvements. Here 'open federalism' once again entailed a hands-off approach in which the federal government did not interact with the provincial governments, but merely allotted money to them and then left them alone to spend it as they would. The Trust is an excellent example of how the federal government can use the spending power to implement pan-Canadian objectives yet it was not in this instance used to its full effect as the government never pressured the provinces into action. So with its limited goals this attempt at collaboration is at best a retracted one that highlights a diminished federal role in the provincial health programs. The federal government mildly deferred to the provinces and the result was that no improvements in the health program could be shown.

In conclusion, I have shown that federal governments over the past two decades have intermittently engaged in deferring authority to provincial governments and that such action has tended to obstruct pan-Canadian policy objectives while also leading to retrenchment and retracted progress in provincial social programs. Collaborative arrangements have been used both to defer federal authority and to reassert it. The AIT, for one, was a deference in the shape of 'collaboration,' where the federal government would not use either its constitutional authority or its spending power to influence the consequently ineffective interprovincial trade agreement; panCanadian trade policy goals lost out. The Trust established for reducing wait times was another deferential collaboration as it put funding largely at provincial discretion resulting in the frustration of small improvements to provincial health care programs. The SUFA and its attendant Health Accord, on the other hand, was a collaboration which at least showed the capacity of the federal government to exercise its spending power, even if it only reaffirmed the principles of the CHA. Unilateral action, usually in connection with the federal spending power, has similarly been used to both pass authority to the provinces and take it away. The UCCB, for instance, was instigated by the Conservative government without any consultation with the provinces and it quickly effected a sort of national child care initiative without provincial involvement, albeit a limited one that replaced a more comprehensive plan. Inversely, the CHST was a unilateral cut that reversed the federal spending power, removing both federal conditions and some legitimacy over provincial programs that led to a retrenchment of social assistance. Ultimately, the federal government has the capacity to create and influence provincial programs to meet panCanadian policy objectives but this capacity depends on the government's inclination to use its spending power.

\footnotetext{
${ }^{52}$ Minaeva, "Canadian Federalism Uncovered: The

Assumed, the Forgotten and the Unexamined in

Collaborative Federalism," 133.

53 Ibid., 133.

${ }^{54}$ Edgar, "The Implications of Open Federalism for Canadian Social Citizenship," 42-43.
} 


\section{Bibliography}

Cameron, Barbara. "The Social Union, Executive Power and Social Rights." Canadian Woman Studies 23, no. $3 / 4$ (Spring/Summer 2004, 2004): 49-56.

Edgar, Steven. "The Implications of Open Federalism for Canadian Social Citizenship." M.A. thesis, Dalhousie University (Canada), 2008.

Edwards, Chris. "Canada's Fiscal Reforms." Cato Journal 33, no. 2 (Apr 2013, 2013): 299-306.

Harles, John, and Jamie Davies. "Federalism Matters: Welfare Reform and the Intergovernmental Balance of Power in Canada and the United States." Canadian - American Public Policy, no. 61 (Jan 2005, 2005): 1-48.

Harmes, Adam. "The Political Economy of Open Federalism." Canadian Journal of Political Science 40, no. 2 (Jun 2007, 2007): 417-437.

Lee, Simon. "The Governance of Fiscal Policy in the United Kingdom and Canada." Journal of Comparative Policy Analysis 5, no. 2-3 (Jun 2003, 2003): 167-187.

Minaeva, Yulia. "Canadian Federalism Uncovered: The Assumed, the Forgotten and the Unexamined in Collaborative Federalism." Ph.D. thesis, University of Ottawa, 2012.

Wilson, Kumanan. "Health Care, Federalism and the New Social Union." Canadian Medical Association Journal 162, no. 8 (Apr 18, 2000, 2000): 1171-4 